\title{
Role of tumor necrosis factor- $\alpha$ in the pathogenesis of indomethacin-induced small intestinal injury in mice
}

\author{
KOHEI FUKUMOTO ${ }^{1}$, YUJI NAITO ${ }^{1}$, TOMOHISA TAKAGI ${ }^{1}$, SHINYA YAMADA $^{1}$, RYUSUKE HORIE $^{1}$, \\ KEN INOUE $^{1}$, AKIHITO HARUSATO ${ }^{1}$, IKUHIRO HIRATA ${ }^{1}$, TASTUSHI OMATSU ${ }^{1}$, KATSURA MIZUSHIMA $^{1}$, \\ YASUKO HIRAI ${ }^{1}$, NAOHISA YOSHIDA ${ }^{1}$, KAZUHIKO UCHIYAMA ${ }^{1}$, TAKESHI ISHIKAWA ${ }^{1}$, OSAMU HANDA ${ }^{1}$, \\ HIDEYUKI KONISHI ${ }^{1}$, NAOKI WAKABAYASHI ${ }^{1}$, NOBUAKI YAGI ${ }^{1}$, SATOSHI KOKURA ${ }^{1}$, \\ HIROSHI ICHIKAWA ${ }^{1}$, MASAKAZU KITA ${ }^{2}$ and TOSHIKAZU YOSHIKAWA ${ }^{1}$
}

Departments of ${ }^{1}$ Molecular Gastroenterology and Hepatology and ${ }^{2}$ Microbiology, Kyoto

Prefectural University of Medicine, Graduate School of Medical Science, Kyoto, Japan

Received October 12, 2010; Accepted November 23, 2010

DOI: $10.3892 / \mathrm{ijmm} .2011 .602$

\begin{abstract}
The pathogenesis of small intestinal damage caused by non-steroidal anti-inflammatory drugs (NSAIDs) such as indomethacin is still unclear. For this reason, there is currently no therapeutic strategy for ameliorating such damage. On the other hand, molecular treatment strategies targeting tumor necrosis factor (TNF)- $\alpha$ exert beneficial effects on intestinal lesions in patients with inflammatory bowel disease (IBD). To clarify the participation of TNF- $\alpha$ in NSAID-induced small intestinal damage, we investigated the effects of indomethacin administration in mice with targeted deletion of the TNF- $\alpha$ gene. Indomethacin $(10 \mathrm{mg} / \mathrm{kg})$ was administered subcutaneously to male C57BL/6 (wild-type: WT) mice and TNF- $\alpha$-deficient (TNF- $\left.\alpha^{-/-}\right)$mice to induce small intestinal damage. The ulcer score, the tissue-associated myeloperoxidase (MPO) activity as an index of neutrophil infiltration, and the expression of keratinocyte chemoattractant (KC) mRNA in the small intestinal mucosa were measured. In addition, we performed a TUNEL assay to evaluate indomethacininduced apoptosis of intestinal epithelial cells and measured the expression of caspase- 3 protein and Bcl-2 mRNA. The ulcer score, MPO activity, and expression of $\mathrm{KC}$ mRNA were significantly increased after indomethacin administration. These increases were significantly inhibited in TNF- $\alpha^{-/-}$mice compared with WT mice. Apoptotic cells were observed by the TUNEL assay in the area of the ulcerative lesion, and they were significantly fewer in TNF- $\alpha^{-/}$mice compared with
\end{abstract}

Correspondence to: Dr Yuji Naito, Department of Molecular Gastroenterology and Hepatology, Kyoto Prefectural University of Medicine, Graduate School of Medical Science, KawaramachiHirokoji, Kamigyo-ku, Kyoto 602-8566, Japan

E-mail: ynaito@koto.kpu-m.ac.jp

Key words: tumor necrosis factor- $\alpha$, indomethacin, small intestine, apoptosis
WT mice. The expression of cleaved caspase-3 protein was induced by indomethacin administration, and significantly inhibited in TNF- $\alpha^{-/}$mice compared with that of WT mice. The expression level of Bcl-2 mRNA in indomethacin-treated TNF- $\alpha^{-1-}$ mice was significantly higher than that in WT mice. TNF- $\alpha$ plays an important role in the pathogenesis of indomethacin-induced small intestinal damage. These results suggest that TNF- $\alpha$ could become a new therapeutic target for NSAID-induced small intestinal damage.

\section{Introduction}

It is well known that non-steroidal anti-inflammatory drugs (NSAIDs) can cause gastrointestinal lesions as an adverse effect in human and experimental animals. Recent advancements in capsule endoscopy $(1,2)$ and double-balloon endoscopy (3) have contributed to the increased diagnosis of NSAID-induced small intestinal lesions such as ulcers, bleeding, perforation, and strictures. As a result, it has become clear that NSAIDinduced small intestinal lesions are not as rare as previously thought (4-7). For example, Morris et al (4) reported that $50-70 \%$ of chronic users of NSAIDs have lesions of the small intestine. However, the pathogenesis of these lesions remains unclear and there is currently no established treatment. A clinically certified therapeutic strategy for preventing NSAIDinduced small intestinal damage awaits further research.

Tumor necrosis factor (TNF)- $\alpha$ is a primary cytokine that initiates the inflammatory cascade by inducing secondary cytokines and key enzymes. TNF- $\alpha$ is produced primarily by activated monocytes/macrophages which play a crucial role in the initiation and continuation of inflammation and immunity (8). TNF- $\alpha$ plays an important role in the progression of inflammatory responses in the gastrointestinal tract as well as in other vital organs. Molecular treatment strategies targeting TNF- $\alpha$ exert extremely beneficial effects on inflammatory bowel disease (IBD) (9) and thus, treatment with anti-TNF- $\alpha$ monoclonal antibodies is widely used for IBD. In contrast, it has been reported that persistent and marked blockage of TNF- $\alpha$ bioactivity may have a detrimental 
effect on acute intestinal inflammation in a dextran sulfate sodium (DSS)-induced colitis model in mice (10). On the other hand, TNF- $\alpha$ is increased in indomethacin-induced intestinal ulcerations in rats and is involved at an early stage of NSAID toxicity in the small intestine (11). TNF- $\alpha$ may up-regulate other cytokines and pro-inflammatory mediators, and thereby cause tissue damage through the gradual rise in serum IL-1 $\beta$ and inducible nitric oxide synthase (iNOS)derived NO levels (12). Immunoneutralization of TNF- $\alpha$ or MCP-1, as well as neutrophil depletion, exerts a preventive effect on indomethacin-induced intestinal damage in rats $(13,14)$. Thus, the role of TNF- $\alpha$ in the pathogenesis of acute intestinal inflammation is still controversial. In this study, we investigated the participation of TNF- $\alpha$ in the pathogenesis of the NSAID-induced small intestinal damage using TNF- $\alpha$ deficient $\left(\mathrm{TNF}-\alpha^{-/}\right)$mice.

\section{Materials and methods}

Animals. In this study, we used 9-week-old male C57BL/6 (WT) mice and age-matched TNF- $\alpha^{-/-}$mice on a C57BL/6 background. Male TNF- $\alpha$ gene-deficient (TNF- $\alpha^{-/}$) mice back-crossed from the mouse strain 129 to $\mathrm{C} 57 \mathrm{BL} / 6 \mathrm{~J}$ were generated by homologous recombination in embryonic stem cells, as described previously (15). Briefly, a TNF- $\alpha$-targeting vector was constructed from a 7-kb DNA fragment isolated from a 129 mouse FIXII genomic library. The HindIIIHincII fragment containing exon III and part of exon IV was replaced by a 1.8-kb PGK-neo gene derived from pKJ1. Germline transmission of the TNF- $\alpha$ mutation was confirmed by Southern blot analysis of murine tail DNA. Homozygotes were crossed with each other to expand the colony, and their progeny were used in the experiments. Male C57BL/6 mice obtained from Shimizu Experimental Animal (Osaka, Japan) were used as WT controls. All animals had free access to food and water, were housed in stainless steel cages with wire bottoms and maintained on a $12 \mathrm{~h}$ light: $12 \mathrm{~h}$ dark cycle, in a $21-23^{\circ} \mathrm{C}$ room with $55-65 \%$ relative humidity. The experiments were performed using 4-7 non-fasting mice per group, unless otherwise specified. The animals were maintained and the experimental procedures carried out in accordance with the National Institutes of Health (NIH) guidelines for the use of experimental animals. All experimental procedures were approved by the Animal Care Committee of the Kyoto Prefectural University of Medicine (Kyoto, Japan).

Induction of small intestinal lesions by indomethacin administration. To induce small intestinal lesions, nonfasted animals were given a single subcutaneous injection of indomethacin (Sigma Chemical, St. Louis, MO) at a dose of $10 \mathrm{mg} / \mathrm{kg}$ according to previous reports $(16,17)$. The animals were sacrificed under deep anesthesia $24 \mathrm{~h}$ after indomethacin administration and the small intestines were removed.

Ulcer score of the small intestine. The jejunum and ileum were opened along the anti-mesenteric attachment, and examined for lesions under a dissecting microscope with square grids. The area $\left(\mathrm{mm}^{2}\right)$ of visible lesions was macroscopically measured as the ulcer score, and summed per small intestine by an observer blinded to the treatment.
Measurement of myeloperoxidase (MPO) activity in tissue samples. Tissue-associated MPO activity in the intestinal mucosa as an index of neutrophil infiltration was measured by a modification of the method of Grisham et al (18). The intestinal mucosa was scraped off using two glass slides, then homogenized with $1.5 \mathrm{ml}$ of $10 \mathrm{mM}$ potassium phosphate buffer ( $\mathrm{pH}$ 7.8) containing $30 \mathrm{mM} \mathrm{KCl}$ in a Teflon Potter-Elvehjem homogenizer. The level of thiobarbituric acid-reactive substances in the mucosal homogenates was expressed as nanomoles of malondialdehyde per milligram of protein using 1,1,3,3-tetramethoxypropane as the standard. Total protein in the tissue homogenates was measured by the method of Lowry (19). Mucosal homogenate (2 ml) was centrifuged at $20,000 \times \mathrm{g}$ for $15 \mathrm{~min}$ at $4^{\circ} \mathrm{C}$ to pelletize the insoluble cellular debris. The pellet was then re-homogenized in an equivalent volume of $0.5 \%$ hexadecyltrimethylammonium bromide. The samples were centrifuged at 20,000 x g for $15 \mathrm{~min}$ at $4^{\circ} \mathrm{C}$, and the supernatants were saved. MPO activity was assessed by measuring the $\mathrm{H}_{2} \mathrm{O}_{2}$-dependent oxidation of 3,3',5,5'- tetramethylbenzidine. One unit of enzyme activity was defined as the amount of MPO that caused the absorbance to change by $1.0 \mathrm{~min}$ at $655 \mathrm{~nm}$ and $25^{\circ} \mathrm{C}$.

RNA analysis. The mRNA expression of intestinal TNF- $\alpha$ was determined by reverse transcription polymerase chain reaction (RT-PCR) and the mRNA expression levels of keratinocyte chemoattractant (KC), Bcl-2 and $\beta$-actin as an internal control were determined by real-time PCR. For both methods, total RNA was isolated from intestinal mucosal tissue by the acid guanidinium phenol chloroform method with an Isogen kit (Nippon Gene, Toyama, Japan), and the RNA concentration was determined by the absorbance at $260 \mathrm{~nm}$ in relation to that at $280 \mathrm{~nm}$. The isolated RNA was stored at $-70^{\circ} \mathrm{C}$ until RT was performed. Extracted RNA $(1 \mu \mathrm{g})$ was reverse-transcribed into first-strand cDNA at $42^{\circ} \mathrm{C}$ for $40 \mathrm{~min}$, using 200 units of M-MLV reverse-transcriptase (Promega, Madison, WI) and $0.5 \mu \mathrm{g}$ of oligo(dT) 15 primer (Takara Biomedicals, Shiga, Japan) in a $20 \mu \mathrm{l}$ reaction mixture. The primers were as follows: for TNF- $\alpha$, sense 5'-ATGAGCACAGAAAGCATGA TC-3' and antisense 5'-TACAGGCTTGTCACTCGAATT-3'; for $\beta$-actin, sense 5'-TGGAATCCTGTGGCATCCA-3' and antisense 5'-TAACAGTCCGCCTAGAAGCA-3'; for $\mathrm{KC}$, sense 5'-TGTCAGTGCCTGCAGACCAT-3' and antisense 5'-CCTGAGGGCAACACCTTCAT-3'; for Bcl-2, sense 5'-GG CATCTGCACACCTGGAT-3' and antisense 5'-CCCAGAC TCATTCAACCAGACA-3'; and for $\beta$-actin, sense 5'-TAT CCACCTTCCAGCAGATGT-3' and antisense 5'-AGCTCA GTAACAGTCCGCCTA-3'. Relative quantification of gene expression with real-time PCR data was calculated relative to $\beta$-actin.

Terminal transferase dUTP nick end labeling (TUNEL) assay. After $24 \mathrm{~h}$ of fixation in formalin, the samples were embedded in paraffin using standard histological procedures. Specimens were cut into $4 \mu \mathrm{m}$ sections. TUNEL staining was performed using an in situ apoptosis detection kit (Takara Biomedicals) according to the manufacturer's instructions. This assay measures DNA strand breaks and is therefore diagnostic for cells undergoing apoptosis. The numbers of positive epithelial cells were quantified by calculating the 
TNF- $\alpha$

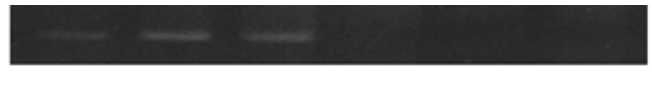

$\beta$-actin

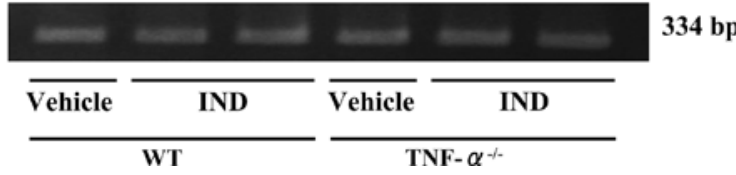

Figure 1. The mRNA expression of intestinal TNF- $\alpha$. TNF- $\alpha$ mRNA was expressed in wild-type (WT) mice and enhanced by indomethacin (IND) administration, but was not detected in TNF- $\alpha^{-/}$mice.

ratio of positive epithelial cells to negatively stained epithelial cells in the small intestinal mucosa.

The expression of caspase-3 protein. The level of protein expression of caspase-3 was evaluated by Western blotting. Proteins were separated by sodium dodecyl sulfate-polyacrylamide gel electrophoresis (SDS-PAGE) and were transferred onto nitrocellulose (Bio-Rad Laboratories, Hercules, CA). Membranes were probed separately with a specific antibody against caspase-3 (Cell Signaling Technology, Beverly, MA). Immune complexes were visualized by Western blotting with a commercial kit (ECL; Amersham, Buckinghamshire, England) according to the manufacturer's recommendations.

Statistical analysis. The results are expressed as means \pm SEM. Differences between two experimental groups were analyzed using Tukey's multiple comparison test. An associated probability ( $\mathrm{p}$-value) of $<5 \%$ was considered statistically significant. All analyses were performed using the program GraphPad Prism 5 (GraphPad Software, San Diego, CA) on a Windows-based computer.

\section{Results}

Effects of TNF- $\alpha$-deficiency on indomethacin-induced injury. We challenged WT and TNF- $\alpha^{-/-}$mice with indomethacin using the same dose. To confirm TNF- $\alpha$ expression, we assessed TNF- $\alpha$ mRNA expression in the small intestine. TNF- $\alpha$ mRNA was expressed in WT mice and was enhanced $24 \mathrm{~h}$ after indomethacin administration as shown by RT-PCR (Fig. 1). In contrast, the expression of TNF- $\alpha$ mRNA was not detected before or after indomethacin administration in TNF- $\alpha^{-/-}$mice (Fig. 1). Macroscopic and microscopic small intestinal ulcerative lesions induced by a single administration of indomethacin at a dose of $10 \mathrm{mg} / \mathrm{kg}$ were observed at $24 \mathrm{~h}$ after the administration (Fig. 2C and D). The development of indomethacin-induced intestinal lesions was significantly suppressed in TNF- $\alpha^{-/}$mice compared with WT mice (Fig. 2C and $\mathrm{D})$. The mean ulcer scores at $24 \mathrm{~h}$ after the administration were $41.7 \pm 12.9 \mathrm{~mm}^{2}$ and $14.8 \pm 9.2 \mathrm{~mm}^{2}$ in WT mice and TNF- $\alpha^{-/-}$mice, respectively $(\mathrm{p}<0.05)$ (Fig. 2E). Typical histological appearances in WT mice and TNF- $\alpha^{-/}$mice are shown in Fig. 3. Administration of indomethacin resulted in ulceration and the infiltration of inflammatory cells throughout the mucosa. The degree of the lesions in TNF- $\alpha^{-/}$mice was obviously lower than that in WT mice.

MPO activity and KC $m R N A$ expression in indomethacininduced small intestinal lesions. MPO activity in the small intestinal tissue was increased after indomethacin administration in both WT mice and TNF- $\alpha^{-/-}$mice (Fig. 4A). The increase in MPO activity in the intestinal mucosa after indomethacin administration was significantly inhibited in $\mathrm{TNF}-\alpha^{-/-}$mice, confirming the results of the histological analysis (Fig. 3). The expression level of $\mathrm{KC} \mathrm{mRNA}$ in the small intestine of

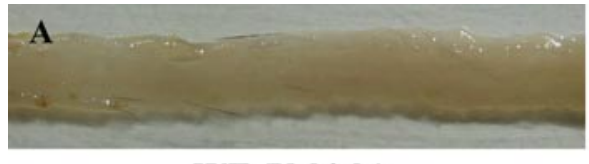

WT (Vehicle)
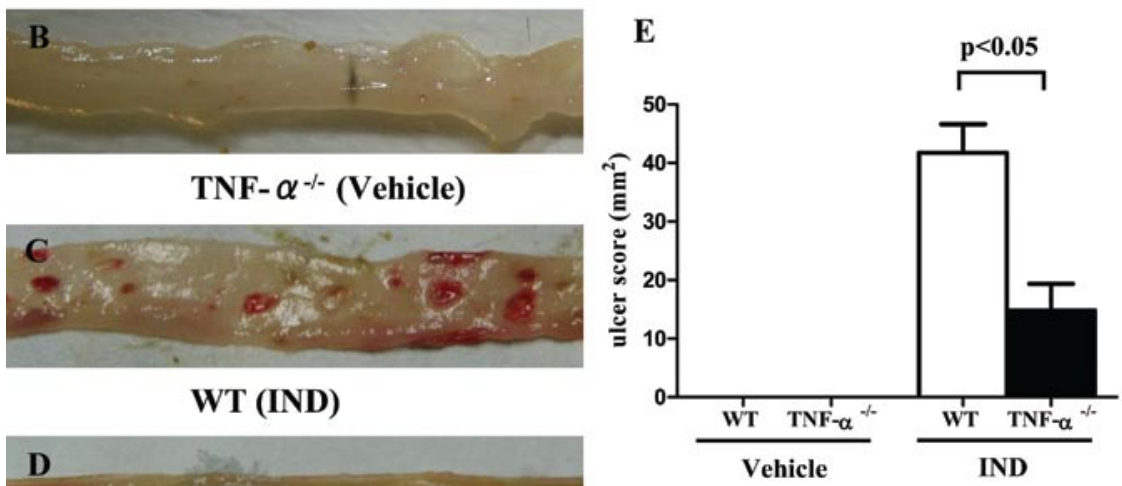

WT (IND)

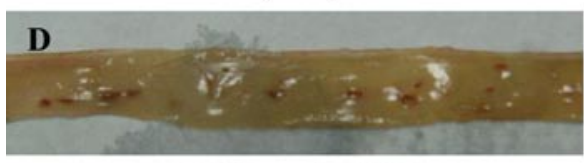

Vehicle

IND

TNF- $\alpha^{-1}$ (IND)

Figure 2. Macroscopic small intestinal lesions induced by indomethacin (IND) administration. (A) Wild-type (WT) mice without IND administration (vehicle). (B) TNF- $\alpha^{-/-}$mice without IND administration (vehicle). (C) WT mice with IND administration. (D) TNF- $\alpha^{-/}$mice with IND administration. Macroscopically, the IND-induced lesions were significantly inhibited in TNF- $\alpha^{-1-}$ mice compared with WT mice. (E) Ulcer scores of WT mice and TNF- $\alpha^{-1-}$ mice. Values are expressed as the mean \pm SEM $(n=4-7)$. Differences were considered significant at $p<0.05$ vs. the WT treated with IND. 


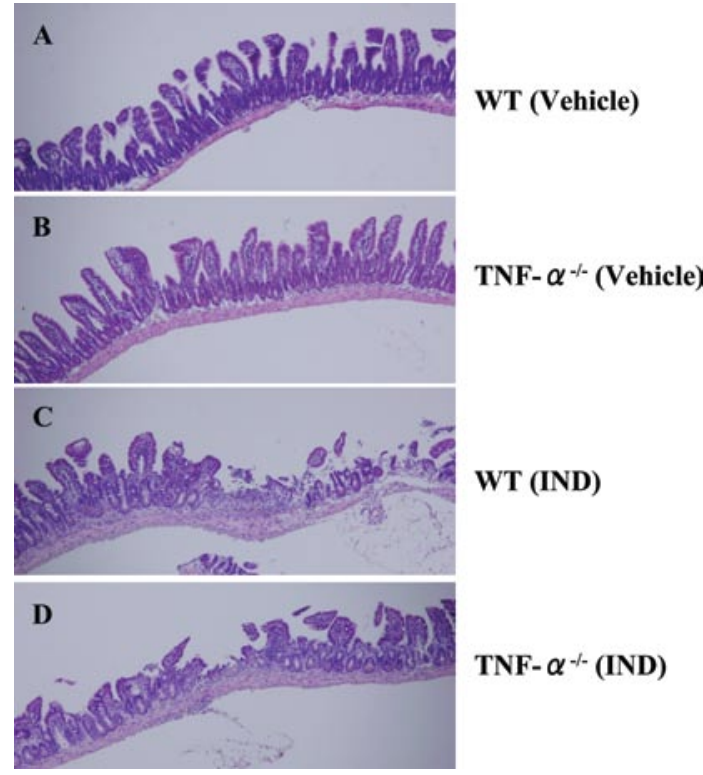

Figure 3. Histological small intestinal lesions after indomethacin (IND) administration. (A) Wild-type (WT) mice without IND administration (vehicle). (B) TNF- $\alpha^{-/}$mice without IND administration (vehicle). (C) WT mice with IND administration. (D) TNF- $\alpha^{-1}$ mice with IND administration. Microscopically, the IND-induced lesions were significantly inhibited in TNF- $\alpha^{-1}$ mice compared with WT mice. indomethacin-treated WT mice was significantly up-regulated compared with that in vehicle-treated mice. It was significantly lower in TNF- $\alpha^{-/-}$mice than in WT mice (Fig. 4B).

Effects of TNF- $\alpha$-deficiency on indomethacin-induced small intestinal epithelial cell apoptosis. To assess the apoptotic cell death in the small intestine, we stained formalin-fixed, paraffin-embedded small intestinal sections by using a TUNEL assay (Fig. 5). The numbers of TUNEL-positive epithelial cells were counted in each of 10 sections and expressed as a percentage of the total epithelial cells. TUNEL-positive cells were observed in the small intestinal mucosa of both WT and TNF- $\alpha^{-1-}$ mice after indomethacin administration (Fig. 5C and D). In comparison to that in WT mice, the number of TUNEL-positive cells in TNF- $\alpha^{-/-}$mice after indomethacin administration was significantly lower (Fig. 5E).

Expression of caspase-3 protein and Bcl-2 mRNA in indomethacin-induced small intestinal lesions. Cleaved products for caspase-3 were detected by Western blot analysis in the small intestinal mucosa $3 \mathrm{~h}$ after indomethacin administration, proving the activation of this protein in the indomethacin-treated small intestine of mice (Fig. 6A). The expression of caspase-3 protein in the small intestinal mucosa
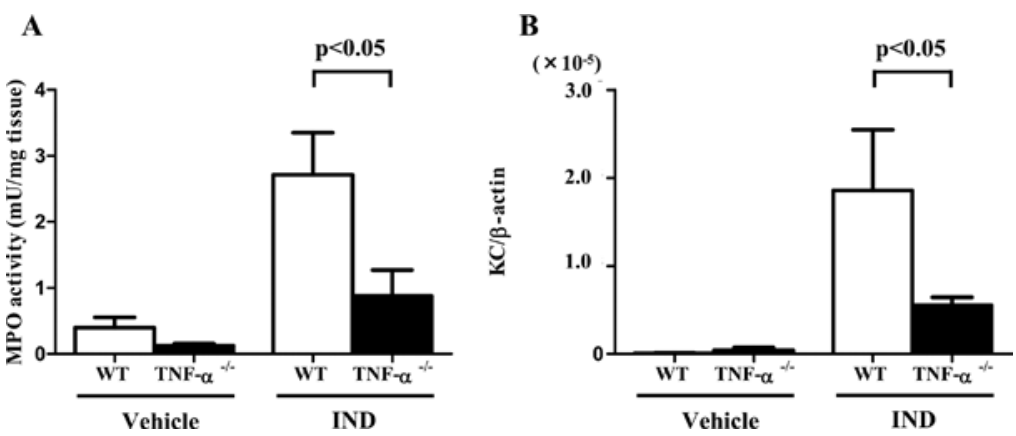

Figure 4. Myeloperoxidase (MPO) activity and the expression level of keratinocyte chemoattractant (KC) mRNA in the small intestinal tissue after indomethacin (IND) administration. (A) The increase of MPO activity after IND administration was significantly decreased in TNF- $\alpha^{-1-}$ mice compared with wild-type (WT) mice. (B) The increase of KC mRNA expression after IND administration was significantly decreased in TNF- $\alpha^{-/-}$mice compared with WT mice. Values are expressed as the mean \pm SEM $(n=5-7)$. Differences were considered significant at $p<0.05$ vs. the WT treated with IND.

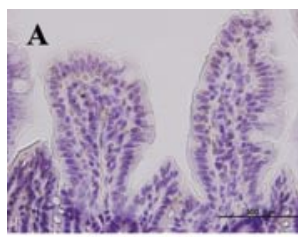

WT (Vehicle)

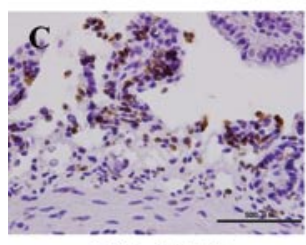

WT (IND)

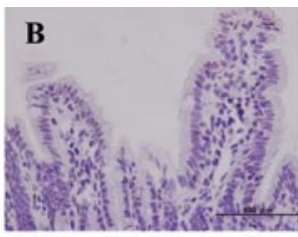

TNF- $\alpha^{-/}$(Vehicle)

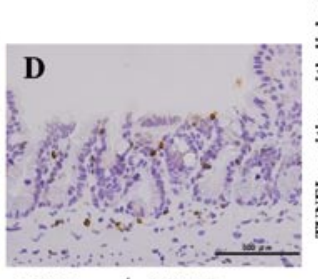

TNF- $\alpha^{-/}$(IND)

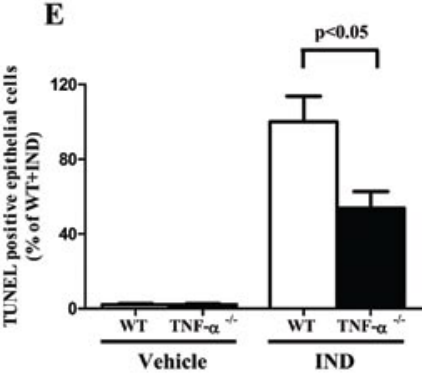

Figure 5. TUNEL assay of the small intestine after indomethacin (IND) administration. (A) Wild-type (WT) mice without IND administration (vehicle) (B) TNF- $\alpha^{-/-}$mice without IND administration (vehicle). (C) WT mice with IND administration. (D) TNF- $\alpha^{-/ /}$mice with IND administration. (E) TUNELpositive cells were observed in the IND-induced small intestinal lesions. These cells were significantly fewer in TNF- $\alpha^{-/}$mice compared with WT mice. Values are expressed as the mean \pm SEM $(n=10)$. Differences were considered significant at $p<0.05$ vs. the WT treated with IND. 
A

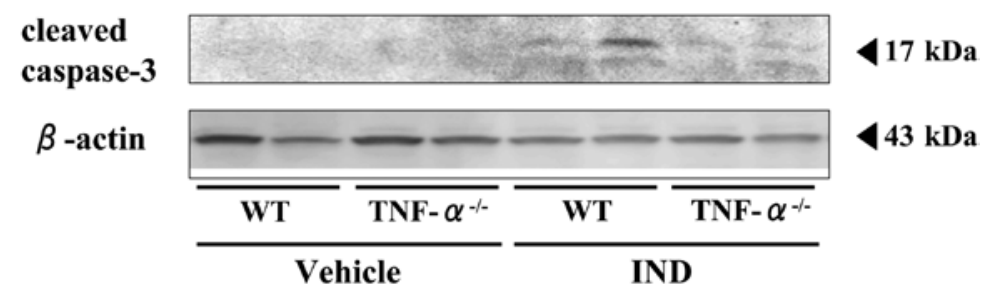

B

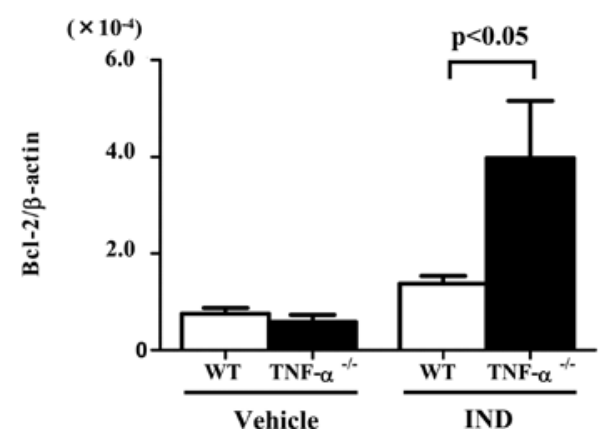

Figure 6. Expression of caspase-3 protein and Bcl-2 mRNA in indomethacin (IND)-treated small intestinal mucosa. (A) Cleaved products for caspase-3 were found by Western blot analysis in the mucosa of the small intestine of mice $3 \mathrm{~h}$ after IND administration. The expression of caspase-3 protein of the small intestinal mucosa was significantly reduced in TNF- $\alpha^{-/-}$mice compared with wild-type (WT) mice. (B) The expression level of Bcl-2 mRNA in the small intestine of IND-treated WT mice was significantly higher than that of WT mice. Values are expressed as the mean \pm SEM ( $=4)$. Differences were considered significant at $\mathrm{p}<0.05$ vs. the WT treated with IND.

was significantly reduced in TNF- $\alpha^{-/-}$mice compared with that in WT mice (Fig. 6A). The expression level of Bcl-2 mRNA in the small intestine of indomethacin-treated TNF- $\alpha^{-1-}$ mice was significantly higher than that of WT mice (Fig. 6B).

\section{Discussion}

In the present study, we demonstrated that TNF- $\alpha$ is involved in small intestinal injury, neutrophil-dependent acute inflammation, and epithelial cell apoptosis after the treatment with indomethacin. First, TNF- $\alpha$ deficiency significantly attenuated indomethacin-induced injury in mice, which was confirmed by macroscopic and histological findings. Second, the acute inflammatory response accompanied with neutrophil accumulation and up-regulation of $\mathrm{KC}$ chemokine after the indomethacin treatment was significantly inhibited in TNF- $\alpha^{-/}$mice compared with WT mice. Finally, the pathway of apoptosis in epithelial cells induced by indomethacin treatment was suppressed by the TNF- $\alpha$ deficiency. The present data suggest that the inhibition of TNF- $\alpha$ can be a novel therapeutic strategy to treat indomethacin-induced small intestinal injury.

Several studies have shown that TNF- $\alpha$ may play a critical role in the pathogenesis of indomethacin-induced small intestinal injury $(11,13,14)$. TNF- $\alpha$ is a pro-inflammatory cytokine capable of up-regulating its own expression as well as the expressions of other genes pivotal to the inflammatory response. The production of TNF- $\alpha$ is generally thought to be harmful to the gastrointestinal system, because portal infusion of TNF- $\alpha$ causes gastric and small intestinal damage in rats, with a nearly total loss of mucosa (20), and TNF- $\alpha$ elicits epithelial barrier defects in colonic cell monolayers (21) and chemokine secretion from intestinal epithelial cells
(22). Several reports have demonstrated the increases in intestinal TNF- $\alpha$ mRNA expression in this model of small intestinal injury (13). Watanabe et al (13) demonstrated that the expression of TNF- $\alpha$ was increased in the small intestine after indomethacin treatment through a Toll-like receptor (TLR) 4-dependent pathway. Bertrand et al (11) also reported that TNF- $\alpha$ production was linked to the toxicity of indomethacin in the small intestine, especially at the early stage of the ulcerogenic process, and that the inhibition of TNF- $\alpha$ synthesis reduced indomethacin-induced intestinal injury in rats. The cytoprotective effects of an anti-TNF- $\alpha$ antibody in a rat model of indomethacin-induced intestinal injury have also been demonstrated (14). To further confirm the role of TNF- $\alpha$ in these injuries, we first showed that the expression of intestinal TNF- $\alpha$ mRNA was increased in WT mice after indomethacin administration, and that these injuries were significantly reduced in TNF- $\alpha^{-/}$mice, as demonstrated by macroscopic and microscopic evaluations. Thus, with respect to in vivo studies of indomethacin-induced intestinal injury, the above observations together with the present data indicate that TNF- $\alpha$ plays a key role in the early phase of the inflammatory process in indomethacin-induced intestinal injury.

Recent studies have hypothesized that activation of neutrophils may be an important prime event that leads to indomethacin-induced intestinal injury. Several lines of evidence support this hypothesis: (i) neutrophil depletion by intraperitoneal injection of anti-neutrophil antibody significantly attenuates the intestinal mucosal injury induced by indomethacin $(13,16)$; (ii) intravital microscopic evaluation of the mesenteric circulation has shown that indomethacin promotes neutrophil adherence and emigration in post-capillary venules (23); and (iii) the induction of intestinal TNF- $\alpha$ production by NSAIDs was followed by activation of the 
neutrophil activation pathway (MPO activity) in the inflammation cascade, which could contribute to jejunum-ileum lesions (11). In this study, we have shown that MPO activity, an index of tissue-associated neutrophil accumulation, and the expression of KC mRNA, which is involved in chemotaxis and cell activation of neutrophils, were remarkably enhanced in the indomethacin-treated intestinal mucosa, and that these increases were significantly reduced in TNF- $\alpha^{-/}$mice compared with WT mice. These results indicate that the inhibition of neutrophil accumulation and $\mathrm{KC}$ chemokine expression by TNF- $\alpha$ deficiency may be one of the protective factors decreasing indomethacin-induced small intestinal mucosal injury.

Several studies have demonstrated that the apoptosis of epithelial cells may play an important role in indomethacininduced intestinal injuries $(24,25)$. Furthermore, in vitro studies using intestinal epithelial cell lines also have indicated that indomethacin induced apoptosis of the intestinal epithelial cells accompanied by an increased production of reactive oxygen species (ROS) $(26,27)$. Omatsu et al $(28)$ have reported that indomethacin induced small intestinal epithelial apoptosis through ROS production and subsequent release of cytochrome $\mathrm{c}$ and smac/DIABLO and the activation of caspase- 3 in vitro. On the other hand, TNF- $\alpha$ is the prototypical member of a family of cytokines that also include the Fas, CD40 and TNF-related apoptosis inducing ligands, and that induce apoptosis, differentiation, cell activation, and inflammation (29). Indomethacin-induced epithelial cell apoptosis in vivo was also reported by Takada et al (30) and Asano et al (31). These authors confirmed that apoptotic cell death occurred in the small intestine treated with indomethacin based on an evaluation of caspases-3/7 activity and a TUNEL assay. In this study, we observed the epithelial cell apoptosis in indomethacin-induced small intestinal lesions by the TUNEL assay, and also showed that the expression of cleaved caspase- 3 by the small intestinal mucosa was significantly enhanced by indomethacin administration. In TNF- $\alpha^{-/-}$mice, the epithelial cell apoptosis and the expression of cleaved caspase-3 in the small intestine were predictably inhibited. These results indicate that the inhibition of apoptosis of small intestinal epithelial cells by TNF- $\alpha$ deficiency may be one of the protective factors contributing to a decrease in indomethacin-induced intestinal damage. However, the precise mechanism underlying indomethacin-induced apoptosis in the small intestinal mucosa is still unclear.

In conclusion, our data demonstrate that TNF- $\alpha$ plays an important role in the pathogenesis of indomethacin-induced small intestinal damage through its involvement in both neutrophil infiltration to the small intestinal mucosa and epithelial cell apoptosis of the small intestine. These results suggest that TNF- $\alpha$ could become a new therapeutic target for NSAID-induced small intestinal damage.

\section{Acknowledgements}

This study was supported by a Grant-in-Aid for Scientific Research (B) to T.Y. (no. 21390184) and (C) to Y.N. (no. 22590705) from the Japan Society for the Promotion of Science; by funds from the City Area Program to T.Y. and Y.N. from the Ministry of Education, Culture, Sports, Science and Technology of Japan; and by funds from the Adaptable and Seamless Technology Transfer Program through Targetdriven R\&D to Y.N. from the Japan Science and Technology Agency.

\section{References}

1. Iddan G, Meron G, Glukhovsky A and Swain P: Wireless capsule endoscopy. Nature 405: 417, 2000.

2. Meron GD: The development of the swallowable video capsule (M2A). Gastrointest Endosc 52: 817-819, 2000.

3. Yamamoto H, Sekine Y, Sato Y, et al: Total enteroscopy with a nonsurgical steerable double-balloon method. Gastrointest Endosc 53: 216-220, 2001.

4. Morris AJ, Madhok R, Sturrock RD, Capell HA and MacKenzie JF: Enteroscopic diagnosis of small bowel ulceration in patients receiving non-steroidal anti-inflammatory drugs. Lancet 337: 520, 1991.

5. Allison MC, Howatson AG, Torrance CJ, Lee FD and Russell RI: Gastrointestinal damage associated with the use of nonsteroidal antiinflammatory drugs. N Engl J Med 327: 749-754, 1992.

6. Bjarnason I, Hayllar J, MacPherson AJ and Russell AS: Side effects of nonsteroidal anti-inflammatory drugs on the small and large intestine in humans. Gastroenterology 104: 1832-1847, 1993.

7. Goldstein JL, Eisen GM, Lewis B, Gralnek IM, Zlotnick S and Fort JG: Video capsule endoscopy to prospectively assess small bowel injury with celecoxib, naproxen plus omeprazole, and placebo. Clin Gastroenterol Hepatol 3: 133-141, 2005.

8. Tracey KJ and Cerami A: Tumor necrosis factor: a pleiotropic cytokine and therapeutic target. Annu Rev Med 45: 491-503, 1994.

9. Rutgeerts PJ: Review article: efficacy of infliximab in Crohn's disease - induction and maintenance of remission. Aliment Pharmacol Ther 13 (Suppl. 4): S9-S15; discussion 38, 1999.

10. Naito Y, Takagi T, Handa O, et al: Enhanced intestinal inflammation induced by dextran sulfate sodium in tumor necrosis factor-alpha deficient mice. J Gastroenterol Hepatol 18: 560-569, 2003.

11. Bertrand V, Guimbaud R, Tulliez M, et al: Increase in tumor necrosis factor-alpha production linked to the toxicity of indomethacin for the rat small intestine. Br J Pharmacol 124: 1385-1394, 1998 .

12. Nandi J, Saud B, Zinkievich JM, Yang ZJ and Levine RA: TNF-alpha modulates iNOS expression in an experimental rat model of indomethacin-induced jejunoileitis. Mol Cell Biochem 336: $17-24,2010$.

13. Watanabe T, Higuchi K, Kobata A, et al: Non-steroidal antiinflammatory drug-induced small intestinal damage is Toll-like receptor 4 dependent. Gut 57: 181-187, 2008.

14. Cury DH, Costa JE, Irika K, et al: Protective effect of octreotide and infliximab in an experimental model of indomethacininduced inflammatory bowel disease. Dig Dis Sci 53: 2516-2520, 2008.

15. Taniguchi T, Takata M, Ikeda A, Momotani E and Sekikawa K: Failure of germinal center formation and impairment of response to endotoxin in tumor necrosis factor alpha-deficient mice. Lab Invest 77: 647-658, 1997.

16. Konaka A, Kato S, Tanaka A, Kunikata T, Korolkiewicz R and Takeuchi K: Roles of enterobacteria, nitric oxide and neutrophil in pathogenesis of indomethacin-induced small intestinal lesions in rats. Pharmacol Res 40: 517-524, 1999.

17. Konaka A, Nishijima M, Tanaka A, Kunikata T, Kato S and Takeuchi K: Nitric oxide, superoxide radicals and mast cells in pathogenesis of indomethacin-induced small intestinal lesions in rats. J Physiol Pharmacol 50: 25-38, 1999.

18. Grisham MB, Hernandez LA and Granger DN: Xanthine oxidase and neutrophil infiltration in intestinal ischemia. Am J Physiol 251: G567-G574, 1986.

19. Lowry OH, Rosebrough NJ, Farr AL and Randall RJ: Protein measurement with the Folin phenol reagent. J Biol Chem 193: 265-275, 1951.

20. Kahky MP, Daniel CO, Cruz AB and Gaskill HV III: Portal infusion of tumor necrosis factor increases mortality in rats. $J$ Surg Res 49: 138-145, 1990.

21. Gitter AH, Bendfeldt K, Schmitz H, Schulzke JD, Bentzel CJ and Fromm M: Epithelial barrier defects in HT-29/B6 colonic cell monolayers induced by tumor necrosis factor-alpha. Ann NY Acad Sci 915: 193-203, 2000. 
22. Abreu-Martin MT, Vidrich A, Lynch DH and Targan SR: Divergent induction of apoptosis and IL-8 secretion in HT-29 cells in response to TNF-alpha and ligation of Fas antigen. J Immunol 155: 4147-4154, 1995.

23. Asako H, Kubes P, Wallace J, Gaginella T, Wolf RE and Granger DN: Indomethacin-induced leukocyte adhesion in mesenteric venules: role of lipoxygenase products. Am J Physiol 262: G903-G908, 1992.

24. Boushey RP, Yusta B and Drucker DJ: Glucagon-like peptide 2 decreases mortality and reduces the severity of indomethacininduced murine enteritis. Am J Physiol 277: E937-E947, 1999.

25. Kamil R, Geier MS, Butler RN and Howarth GS: Lactobacillus rhamnosus GG exacerbates intestinal ulceration in a model of indomethacin-induced enteropathy. Dig Dis Sci 52: 1247-1252, 2007.

26. Fuji Y, Matsura T, Kai M, Kawasaki H and Yamada K: Protection by polaprezinc, an anti-ulcer drug, against indomethacin-induced apoptosis in rat gastric mucosal cells. Jpn J Pharmacol 84: 63-70, 2000 .
27. Nagano Y, Matsui H, Muramatsu M, et al: Rebamipide significantly inhibits indomethacin-induced mitochondrial damage, lipid peroxidation, and apoptosis in gastric epithelial RGM-1 cells. Dig Dis Sci 50 (Suppl. 1): S76-S83, 2005.

28. Omatsu T, Naito Y, Handa O, et al: Reactive oxygen speciesquenching and anti-apoptotic effect of polaprezinc on indomethacin-induced small intestinal epithelial cell injury. J Gastroenterol 45: 692-702, 2010.

29. Bazzoni $\mathrm{F}$ and Beutler B: The tumor necrosis factor ligand and receptor families. N Engl J Med 334: 1717-1725, 1996.

30. Takada M, Otaka M, Takahashi T, et al: Overexpression of a $60-\mathrm{kDa}$ heat shock protein enhances cytoprotective function of small intestinal epithelial cells. Life Sci 86: 499-504, 2010.

31. Asano T, Tanaka K, Yamakawa N, et al: HSP70 confers protection against indomethacin-induced lesions of the small intestine. J Pharmacol Exp Ther 330: 458-467, 2009. 